\title{
Public Health Issues from the Exposure to Nitrogen Oxides: A Brief Review
}

\author{
Margarita Theodorakidou ${ }^{1}$, George I. Lambrou ${ }^{1,2^{*}}$ \\ ${ }^{I}$ First Department of Pediatrics, National and Kapodistrian University of Athens, Choremeio Research \\ Laboratory, Haematology and Oncology Unit, Athens, Greece \\ ${ }^{2}$ Post-Graduate Program "Public Health", National School of Public Health (NSPH), Athens, Greece
}

*Corresponding Author: George I. Lambrou,First Department of Pediatrics, National and Kapodistrian University of Athens, Choremeio Research Laboratory, Haematology and Oncology Unit, Thivon \& Levadeias, 11527, Goudi Athens, Greece, Email: glamprou@med.uoa.gr

\begin{abstract}
Changes in the modern way of life happened due to the industrial revolution, along with the evolution and increase in the use of technology. Despite the existing benefits, these changes caused the accumulation of pollutants and the proliferation of environmental pollution. From this perspective, the problem of exposure of humans to pollutants and contaminants in everyday life and working environments has been emerged. Air pollutants are a special category of which an interesting subcategory is the pollutants of nitrous oxides, rising sharply in the years of industrialization and automation of human life. In the present study, we will examine the properties of air pollutants, and in particular those of nitric oxides, referring to their environmental impacts and hence to the working environment, since the effects are similar along with some public health issues emerging from human exposure to the oxides of nitrogen.
\end{abstract}

Keywords: Public Health, Nitrogen, Nitric Oxides, Exposure

\section{List of Abbreviations}

\begin{tabular}{|l|l|}
\hline Abbreviation & \\
\hline EU & European Union \\
\hline$N O_{x}$ & Nitrogen Oxides \\
\hline ppm & Parts per million \\
\hline EDRF & Endothelium Derived Relaxing Factor \\
\hline NOS & Nitric Oxide Synthases \\
\hline NADPH & Nicotinamide Adenine Dinucleotide Phosphate \\
\hline EDHF & Endothelium-Derived Hyperpolarizing Factor \\
\hline UV & Ultraviolet \\
\hline OECD & The Organization for Economic Co-operation and Development \\
\hline PAHs & polycyclic aromatic hydrocarbons \\
\hline VOCs & Volatile Organic Compounds \\
\hline PIARC & Permanent International Association of Road Congresses (now World Road Association) \\
\hline
\end{tabular}

\section{INTRODUCTION}

Environmental pollutants are considered to be one of the main problems in the modern way of life and its aftereffects. Two parameters are involved: everyday life, where a person is burdened with pollution loads and secondly the working environment. The industrial revolution brought to light what is now called environmental pollution. Therefore, along with the industrial revolution, there have also been professions forcing workers into exposure to environmental pollutants[1-5].
From this point of view, issues of safety and exposure to the corresponding biochemical pollutants arise. A major pollutant category is atmospheric pollutants or, in general, air pollutants where nitrogen oxides appertain.

A fact of great interest is not only the latest reports of the European Union (EU) on the situation in the Member States regarding the concentrations of nitrogen oxides $\left(N O_{x}\right)$, but for example also the reduction of life expectancy to the range of six months in Greece, according to the tables presented by scientists in the field. 
Air pollutants in the atmosphere of industrial centers are of large amount generated both by fixed installations (e.g. industrial units, power generating stations) and by vehicles as well. Although inhalation of toxic substances during occupational exposure to individual professional groups has been adequately studied, the study of the effect of common toxic environmental pollutants on health has begun to be in medical science relatively recent $[4,5]$.

The large increase of deaths in London from the 1952 London "Big Smoke" or "The Great Smoke" and similar events in the 1960s in New York, led to stricter limits on environmental pollutants introduced by special legislation and organized systematic researches. Audit findings were applied to the conditions of the working environment $[6,7]$. However, the moment the legislator establishes the regulations does not mean the direct application of the law. Therefore, to control the new environmental conditions, safety levels of certain substances began to be stipulated such as sulfur dioxide, nitrogen dioxide, ozone, lead, carbon monoxide and particles with a diameter less than $10 \mu \mathrm{m}$. As known, the chemical structure of various pollutants changes during their stay in the atmosphere[8].

Sulfur dioxide can react with particulate dust, resulting in the formation of sulphates that are components of acid rain. Nitrogen oxides and compounds/by-products of fuel combustion by vehicle exhausts react with sunlight resulting in ozone production.

Ozone production can reach particular high levels during hot weather especially in countries where temperatures rise during the summer months and where a great amount of people experience eye or mucosal irritation and cardiopulmonary problems due to these conditions.

According to several reports, the type of diseases caused by the pollutant depends on its ability to be transferred to the lower tracheobronchial tree in the terminal bronchioles and alveoli, its quantity and chemical structure, its defense capability and finally the sensitivity of the organism against toxic effects, timing and duration of exposure[8].

According to these studies, high solubility gases such as sulfur dioxide are predominantly absorbed by the upper airways, leading to corresponding symptoms in acute exposure (nasal irritation).

Gases of lesser solubility, such as nitrogen dioxide $\left(\mathrm{NO}_{2}\right)$, reach up to respiratory bronchioles and alveoli resulting in pulmonary irritation at acute exposure (dyspnea, disruption of pulmonary function).

Similarly, large particles are retained by the upper airways; smaller diameter particles penetrate the lower tracheobronchial tree and the lung, while particles with a diameter of less than $0.1 \mu \mathrm{m}$ tend to remain airborne and may only accidentally come in contact with the alveolar wall[9, 10].

Atmospheric pollutants can generally cause coughing, seizing up of the nostrils, dyspnea and eye ailments in acute exposure. Chronic exposure may generally cause a reduction in respiratory redundancy, and according to some studies, increase of carcinogenicity rates[11, 12].

The type of diseases the body suffers from and its health status are factors of great importance. Allergic individuals may have acute symptoms even in cases of minor exposure. The adverse effects of pollutants increase in lung disease or heart disease patients and smokers. In 1952, in London, studies attributed 4,000 deaths to the smog.

\subsection{About Oxides and Oxides of Nitrogen}

During the 18th century, the oxides were called calxes or calces because they were produced by calcinations. Later on they were named oxides. Oxides are compounds of chemical elements with oxygen[13]. A large part of the earth's crust consists of oxides. Oxides are formed when the various chemical elements are oxidized by the oxygen of the atmosphere. Even materials such as aluminum foil, which appear to be composed of pure chemical elements, are often coated with a thin layer of oxides that protect them from corrosion[13].

Oxides are either molecular compounds (when the element is non-metal) or ionic compounds (when the element is a reactive metal) or macromolecular compounds (they are in the form of a "giant" molecule) such as the oxide of the formula $\left[\mathrm{K}_{2} \mathrm{O}\right]_{n}$. In addition to oxygen difluoride with the formula $O F_{2}$, the oxides have the electronegative section of $O^{-2}$ and can be 
represented as follows: $E_{y} O_{x}$, where $E$ is a chemical element, $x$ is one of the positive numbers of oxidation of $\mathrm{E}$ and $y$ the number of oxygen oxidation which may be $-2,-1,-1 / 2$. Examples of chemical formulas of oxides are $\mathrm{Na}_{2} \mathrm{O}, \mathrm{CaO}, \mathrm{CO}_{2}, \mathrm{SO}_{3}, \mathrm{~N}_{2} \mathrm{O}_{5}, \mathrm{~N}_{2} \mathrm{O}_{3}, \mathrm{KO}_{2}$, $\mathrm{Na}_{2} \mathrm{O}_{2}$ and others[14].

Oxides are classified by various criteria: Based on the amount of oxygen, based on the amount of oxygen contained and corresponding to the usual oxidation numbers (Oxidation State (OS)) of the element. Oxygen has an oxidation state of -2 , whereas Carbon $(C)$ has an oxidation state of +4 . Thus, a normal oxide would be carbon dioxide $\left(\mathrm{CO}_{2}\right)$ but not carbon monoxide $(\mathrm{CO})$. Sulfur $(S)$ has two most common OS which are +4 and +6 . So its regular oxides would be sulfur dioxide $\left(\mathrm{SO}_{2}\right)$ and sulfur trioxide $\left(\mathrm{SO}_{3}\right)$ respectively, etc. In several oxides, the participating oxygen reacts with lower OS. Examples of such reactions are carbon monoxide $(\mathrm{CO})$ where $C$ reacts with an OS of $+2, N_{2} O(N$ has an OS of +1$)$ and so on. Oxygen tends to become normal by oxygen uptake as for example in the reaction $\mathrm{N}_{2} \mathrm{O}+1 / 2 \mathrm{O}_{2} \longrightarrow 2 \mathrm{NO}$. Several molecules known as peroxides, contain more oxygen than that corresponding to the higher OS of the element. Peroxides contain the peroxy bond or peroxy group, which is formed as -O-O- or $\mathrm{O}_{2}{ }^{2-}$ wherein each oxygen atom has an $\mathrm{OS}$ of -1 . Examples of peroxides are, hydrogen peroxide $\mathrm{H}_{2} \mathrm{O}_{2}$ (with a general structure $\mathrm{H}-\mathrm{O}-\mathrm{O}-\mathrm{H}), \mathrm{Na}_{2} \mathrm{O}_{2}$ (Na-O-O-Na), $\mathrm{BaO}_{2}$ $\left(\mathrm{Ba}^{2+}-\mathrm{O}-\mathrm{O}\right)$ and so on. Peroxides react with dilute acid solutions as for example in the following reaction;

$\mathrm{K}_{2} \mathrm{O}_{2}+2 \mathrm{HCl} \longrightarrow 2 \mathrm{KCl}+\mathrm{H}_{2} \mathrm{O}_{2}$, but also with water as $\mathrm{Na}_{2} \mathrm{O}_{2}+2 \mathrm{H}_{2} \mathrm{O} \longrightarrow 2 \mathrm{NaOH}+\mathrm{H}_{2} \mathrm{O}_{2}$ [15].

Some other examples of oxides are the mixed or complex oxides, also known as epiquadroxides. In those compounds, the element appears with two different OS as for example $\mathrm{Fe}_{3} \mathrm{O}_{4}\left(\mathrm{Fe}_{2} \mathrm{O}_{3}\right.$, $\mathrm{FeO}), \quad \mathrm{Pb}_{3} \mathrm{O}_{4} \quad\left(\mathrm{PbO}_{2}, \quad 2 \mathrm{PbO}\right), \quad \mathrm{Mn}_{3} \mathrm{O}_{4}$ $\left(\mathrm{MnO}_{2} \cdot 2 \mathrm{MnO}\right)$. They are generally classified into four major categories:

a. Acid oxides, or acid anhydrides, or acidic, or covalent oxides. They are the normal oxides of non-metal and metal oxides, where metal has an $\mathrm{OS}>+3$, e.g. $\mathrm{SO}_{3}, \mathrm{~N}_{2} \mathrm{O}_{5}, \mathrm{P}_{2} \mathrm{O}_{5}, \mathrm{Mn}_{2} \mathrm{O}_{7}$, $\mathrm{CrO}_{3}$, and others. They usually have a double bond in their molecule such as the $\mathrm{CO}_{2}$ having a general structure of $O=C=O$ structure. In addition, there are acidic oxides with single bond[15].

b. Oxides of the formula $E_{2} O$ (where $E$ is an element) which forms bonds of the type $E-O$ $E$. Single bonds are able to rotate and form angles with the oxygen molecule, where the degrees of the angle and element rotation form an angle the value of which depends on the kind of element $\Sigma$. The acidic oxides can be obtained by removing water from the acids e.g. $\mathrm{H}_{2} \mathrm{SO}_{4}-\mathrm{H}_{2} \mathrm{O} \rightarrow \mathrm{SO}_{3}$ and are also called acid anhydrides.

These oxides are also called acid or acidic because many of them react with water and give the corresponding acids e.g. $\mathrm{N}_{2} \mathrm{O}_{5}+\mathrm{H}_{2} \mathrm{O}$ $\rightarrow 2 \mathrm{HNO}_{3}[15]$.

Exceptions are the slightly soluble $\mathrm{SiO}_{2}, \mathrm{~B}_{2} \mathrm{O}_{3}$ anhydrides that do not react with water. Acid oxides are Lewis acids irrespectively of their presence in aqueous solution or not. However, they are acids by Arrhenius and Brönsted-Lowry only in aqueous solutions[15].

Metal oxides, or base anhydrides, or basic, or ionic, or metallic oxides are the normal metal oxides where the metal has an OSof +1 or +2 e.g. $\mathrm{K}_{2} \mathrm{O}, \mathrm{CaO}, \mathrm{BaO}$ and so on. They are also called base anhydrides because they result from the hydroxides of the respective metals by removing water, e.g. $\mathrm{Ca}(\mathrm{OH})_{2}-\mathrm{H}_{2} \mathrm{O} \rightarrow \mathrm{CaO}$.

Oxides of $\mathrm{Li}_{2} \mathrm{O}, \mathrm{Na}_{2} \mathrm{O}, \mathrm{K}_{2} \mathrm{O}, \mathrm{CaO}, \mathrm{BaO}, \mathrm{MgO}$ are also called bases because they react with water and give the corresponding bases as for example $\mathrm{K}_{2} \mathrm{O}+\mathrm{H}_{2} \mathrm{O} \rightarrow 2 \mathrm{KOH}$.

The basic oxides are by Lewis and BrönstedLowry acids either in aqueous solution or not. However, they are acids by Arrhenius only in aqueous solution. The formation of a metal oxide requires sufficient energy $(>1000 \mathrm{KJ} / \mathrm{mol}$ ) and their stability is due to the high energy value of the crystal lattice[15].

Amphoteric oxides are certain normal metal oxides which, when treated with an acid, behave as bases and when treated with base behave like acids.

Neutral oxides do not react with water to give acids or bases nor do they come from these compounds by removing water. Such an oxide is $\mathrm{CO}$. Others are the oxides (e.g., $\mathrm{N}_{2} \mathrm{O}$ ), peroxides (e.g., $\mathrm{Na}_{2} \mathrm{O}_{2}$ ) and mixed oxides. Oxides derived 
from metals are named as "MetalOxide",e.g. $\mathrm{Na}_{2} \mathrm{O}$ is names sodium oxide, $\mathrm{CaO}$ is named calcium oxide, $\mathrm{FeO}$ is named iron oxide (II), $\mathrm{Fe}_{2} \mathrm{O}_{3}$ is named iron oxide (III), and $\mathrm{CrO} 3$ is named chromium (VI) oxide and so on. Oxides are also called some macromolecular compounds e.g. [MgO $]_{n}$ magnesium oxide, $\left[\mathrm{SiO}_{2}\right]_{n}$ silicon oxide and so on. $\mathrm{NO}, \mathrm{NO}_{2}$ and $\mathrm{SO}_{2}$ come from oxidation reactions of elements from concentrated and dilute $\mathrm{HNO}_{3}$ and concentrated $\mathrm{H}_{2} \mathrm{SO}_{4}$ as well. Examples of these reactions are:

$$
\begin{aligned}
& \mathrm{S}+2 \mathrm{H}_{2} \mathrm{SO}_{4} \rightarrow 3 \mathrm{SO}_{2}+2 \mathrm{H}_{2} \mathrm{O} \\
& 3 \mathrm{Cu}+8 \mathrm{HNO}_{3} \quad(\text { dilute }) \rightarrow 3 \mathrm{Cu}\left(\mathrm{NO}_{3}\right)_{2}+2 \mathrm{NO}+ \\
& 4 \mathrm{H}_{2} \mathrm{O} \\
& \mathrm{Zn}+4 \mathrm{HNO}_{3} \\
& (\text { concentrate }) \rightarrow 2 n\left(\mathrm{NO}_{3}\right)_{2}+2 \mathrm{NO}_{2}+2 \mathrm{H}_{2} \mathrm{O}
\end{aligned}
$$

Further on, water has an effect on oxides and in particular on $\mathrm{NO}_{2}, \mathrm{Na}_{2} \mathrm{O}_{2}, \mathrm{CO}$ as per the reactions:

$$
\begin{aligned}
& 3 \mathrm{NO}_{2}+\mathrm{H}_{2} \mathrm{O} \longrightarrow 2 \mathrm{HNO}_{3}+\mathrm{NO} \\
& \mathrm{Na}_{2} \mathrm{O}_{2}+\mathrm{H}_{2} \mathrm{O} \longrightarrow 2 \mathrm{NaOH}+1 / 2 \mathrm{O}_{2} \text { and } \\
& \mathrm{CO}+\mathrm{H}_{2} \mathrm{O} \rightleftarrows \mathrm{CO}_{2}+\mathrm{H}_{2}
\end{aligned}
$$

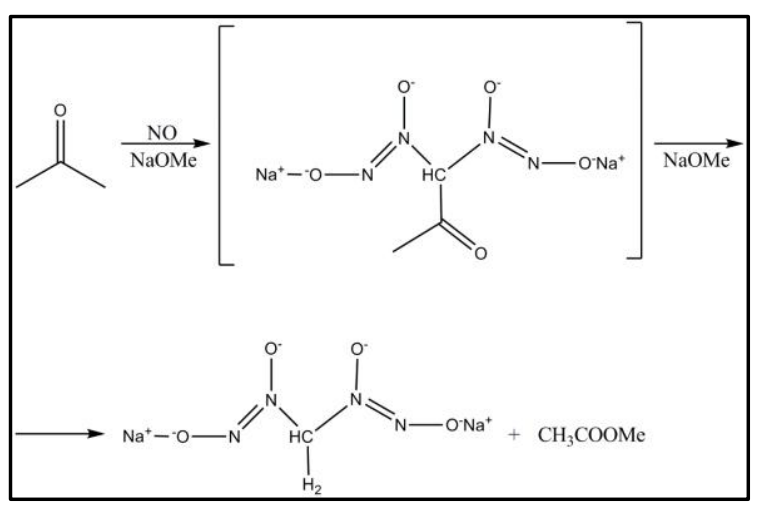

Figure1. The reaction of nitric oxide (NO) with carbanions is one ofthe most often-used methods for the preparation of carbon-bounddiazeniumdiolates (compounds also called nitrosohydroxylamines).The reaction of monoxide is used in the research of novel pharmaceutical products, where the compound is used as an intermediate objective or as a premedicinal product. Sodium methoxide remains the preferred basefor effecting the deprotonation of a variety of substrates to besubjected to this "Traube reaction" since Wilhelm Traube first introduced the procedureover 100 years ago(Bohle and Smith 2008, Derosa, Keefer et al. 2008).

The term "nitrogen oxide" is considered to be inaccurate and can be used to refer to any of the oxides of nitrogen, or a mixture thereof nitrogen oxides are considered to be Nitric oxide $(N O)$, nitrate (II) oxideNitrogen dioxide $\left(\mathrm{NO}_{2}\right)$, Dinitrogen Oxide $\left(\mathrm{N}_{2} \mathrm{O}\right)$ (or known also as Nitrous Oxide), Dinitrogen trioxide $\left(\mathrm{N}_{2} \mathrm{O}_{3}\right)$, Dinitrogen tetroxide $\left(\mathrm{N}_{2} \mathrm{O}_{4}\right), \quad$ Dinitrogen pentoxide $\left(\mathrm{N}_{2} \mathrm{O}_{5}\right)$. A mixture is often formed in the chemical reactions of nitrogen oxides and their products, in such proportions, depending on the specific reaction and the conditions being carried out. Nitrogen monoxide or nitric oxide is an interesting chemical compound case. Its physical state is gas and consists of two atoms, oxygen and nitrogen. In addition to its properties as atmospheric gas, it is also an important signaling molecule in eukaryotic cells [16]. It is also a very important synthetic material in the industry. The monoxide, when exposed to oxygen, is converted to nitrogen dioxide according to the reaction $2 \mathrm{NO}+$ $\mathrm{O}_{2} \rightarrow 2 \mathrm{NO}_{2}$.

$N O$ reacts with fluoride, chlorine and bromine to form halogenated compounds. An interesting reaction of monoxide is used in the research of novel pharmaceutical products, where the compound is used as an intermediate objective or as a pre- medicinal product[17]. This reaction is very old (1898) and is used so far, based on the formula presented in Figure 1.

From an environmental point of view, $N O$ in the atmosphere may form nitric acid, main component in acid rain. At the same time, monoxide and nitrogen dioxide are involved in the creation of the ozone hole. $N O$ is one of the few gases known to be involved in cell signaling. It is also known as Endothelium Derived Relaxing Factor (EDRF) and is composed of L-Arginine, Oxygen and NADPH with the involvement of enzymes known as Nitric Oxide Synthases (NOS).Its functions are associated with vascular endothelium relaxation, platelet function, and adhesion of leukocytes to endothelial tissue. This is one of the many reasons why environmental burden affects the cardiovascular and respiratory system [18]. It is also excreted by the immune system cells as antibacterial protection acting as a free radical and destroying the DNA of the bacteria[19].The physical state (solid, liquid and gas), water solubility and some important uses of certain oxides are shown in Table 1. 
Table1. Summary of chemical types of oxides and their respective physical and water solubility states

\begin{tabular}{|c|c|c|c|}
\hline $\begin{array}{l}\text { Chemical } \\
\text { type of } \\
\text { oxide }\end{array}$ & $\begin{array}{c}\text { Physical } \\
\text { state }\end{array}$ & $\begin{array}{c}\text { Water } \\
\text { solubility }\end{array}$ & Uses \\
\hline $\begin{array}{l}\text { Metal } \\
\text { oxides }\end{array}$ & Solid & No & $\begin{array}{l}\text { Glass industry, } \\
\text { pharmaceutical } \\
\text { industry, batteries }\end{array}$ \\
\hline $\mathrm{Na}_{2} \mathrm{O}_{2}$ & Solid & Yes & $\begin{array}{l}\text { Oxygen production, } \\
\text { oxidant, bleaching } \\
\text { product }\end{array}$ \\
\hline $\mathrm{BaO}$ & Solid & Yes & $\begin{array}{l}\text { Production of } \\
\mathrm{Ba}(\mathrm{OH})_{2}\end{array}$ \\
\hline $\mathrm{Na}_{2} \mathrm{O}$ & Solid & Yes & $\begin{array}{l}\text { Glass industry, } \\
\text { production } \\
\mathrm{NaOH}\end{array}$ \\
\hline $\mathrm{CaO}$ & Solid & Slow & $\begin{array}{l}\text { Mortars, desiccants, } \\
\text { production of } \mathrm{CaCl} \\
\text { and } \\
\text { Calcium carbide }\end{array}$ \\
\hline $\mathrm{MgO}$ & Solid & Slow & $\begin{array}{lr}\text { Refractory } & \text { bricks, } \\
\text { crucibles, } & \text { light } \\
\text { laxatives } & \end{array}$ \\
\hline $\begin{array}{l}\mathrm{CO}, \mathrm{NO}, \\
\mathrm{N}_{2} \mathrm{O}, \mathrm{NO}_{2}\end{array}$ & Gas & No & $\begin{array}{l}\mathrm{CO} \text { as fuel in } \\
\text { metallurgy, nitrogen } \\
\text { oxides in acid } \\
\text { production }\end{array}$ \\
\hline $\mathrm{SO}_{2}$ & Gas & Yes & $\begin{array}{l}\text { Coolant, bleaching } \\
\text { product, antiseptic } \\
\text { and in production of } \\
\mathrm{H}_{2} \mathrm{SO}_{4}\end{array}$ \\
\hline $\begin{array}{l}\mathrm{NO}_{2} \\
\mathrm{~N}_{2} \mathrm{O}_{3}\end{array}$ & Liquid & Yes & $\begin{array}{l}\text { Production of nitric } \\
\text { acid }\end{array}$ \\
\hline $\mathrm{SiO}_{2}$ & Solid & No & $\begin{array}{l}\text { Manufacture of } \\
\text { optical instruments, } \\
\text { building, dynamite }\end{array}$ \\
\hline $\mathrm{CO}_{2}$ & Gas & Slow & $\begin{array}{l}\text { refreshments, fire } \\
\text { extinguishers, } \\
\text { coolant }\end{array}$ \\
\hline $\mathrm{H}_{2} \mathrm{O}_{2}$ & Liquid & Yes & $\begin{array}{l}\text { Bleaching product, } \\
\text { antiseptic, peroxide } \\
3 \% \mathrm{w} / \mathrm{v}\end{array}$ \\
\hline
\end{tabular}

\subsection{Nitrous Oxide}

Nitrogen dioxide or nitrous oxide is a chemical compound of formula $\mathrm{NO}_{2}$. It is the intermediate component for the synthesis of nitric acid. This gas is toxic and is one of the main atmospheric pollutants. It has a molecular weight of 46.0055 , is heavier than air and is therefore concentrated in the lower layers of gas masses.

Dioxide is in equilibrium with Nitrogen tetroxide $\left(\mathrm{N}_{2} \mathrm{O}_{4}\right)$ based on the reaction2 $2 \mathrm{NO}_{2} \rightleftharpoons$ $\mathrm{N}_{2} \mathrm{O}_{4}$.

\subsection{Environmental Toxicology of Gaseous Pollutants}

Environmental Toxicology has established important research disciplines for the effects of air pollution on living organisms, with a particular focus on urban residents. Air pollution is mainly associated with gaseous pollutants, aerosols and suspended particles emitted from a wide range of pollutants (such as cars, industries, crafts, power plants, etc.). These pollutants can enter the lungs by breathing, mainly causing respiratory problems and the effect on plants and animals can cause various damages to living tissues. Initial studies into the toxic effects of gaseous pollutants were carried out in the working environment where professionals were in a high concentration environment and their exposure was long-lasting [20-23]. Workers received the effects of toxic and dangerous substances, mixtures of substances and physical agents, resulting in significant damage to their health (occupational diseases, occupational cancer, and chronic lung diseases). In contrast to large cities, factories and craft industries concentrations of toxic substances and exposure in the natural environment are much lower and the severity of the effects depends on exposure duration, age and lifestyle [20-23].

The term atmospheric pollution covers a wide range of toxic gaseous pollutants and suspended particles emitted into the planet's troposphere $(0-15 \mathrm{~km})$, as well as the variety of photochemical secondary pollutants and other atmospheric phenomena resulting from anthropogenic emissions. The stratosphere (15$50 \mathrm{~km}$ ) is the area where the thin layer of ozone is predominant, with the main purpose of protecting life on our planet from the ultraviolet rays of solar radiation. The main sources of air pollution are vehicle exhaust emissions, emissions from factories and crafts (mainly from fossil fuels for energy production and dust from material treatment), power stations, central heating of homes, burning waste and agricultural residues, gaseous emissions from agriculture and livestock farming and natural emissions of plants and trees. The main pollutants are carbon monoxide and carbon dioxide $\left(\mathrm{CO}, \mathrm{CO}_{2}\right)$, sulfur dioxide $\left(\mathrm{SO}_{2}\right)$, nitrogen oxides $\left(N O_{x}\right)$, volatile organic compounds (VOCs), and suspended particulate matter, exhaust gases, industrial installations, building construction and volcanic activity. The most significant emissions of air pollution 
concern carbon dioxide $\left(\mathrm{CO}_{2}\right)$, a nontoxic gas but with excessive atmospheric concentration that contributes to the greenhouse effect [24-26]. On a global scale, $\mathrm{CO}_{2}$ emissions of 14,520,000 tons in 1971 doubled to around 30,000,000 tons in 2000 with a surge in demand for energy from developing countries (China, India, etc.) [27, 28]. Numerous researches show that greenhouse gases have a key role in ecosystems and in the main cycles of nutrients and elements [29, 30]. Carbon monoxide $(\mathrm{CO})$ is an extremely toxic gas produced by $70-80 \%$ of car exhaust emissions. $\mathrm{CO}_{2}$ emissions from vehicles and industries are estimated at around 200 million tons, of which $70 \%$ regards OECD countries (Organization for Economic Cooperation and Development; an organization of the 24 most developed industrialized countries based in Paris). Similar amounts of $C O$ are produced globally by forest fires and biomass burning. Sulfur dioxide $\left(\mathrm{SO}_{2}\right)$ is a sufficiently toxic gaseous pollutant for the natural environment. $\mathrm{SO}_{2}$ is the result of the use of high sulfur fossil fuels as well as volcanic emissions. It is estimated that $\mathrm{SO}_{2}$ emissions in the 1980s were around 100 million tons, of which $40 \%$ proceeded from OECD countries. $\mathrm{SO}_{2}$ emissions have decreased significantly due to the improvement of fuel (desulphurization). In addition to the effects on human health in urban areas with increased air pollution, $\mathrm{SO}_{2}$ causes damage to building surfaces and when vaporsoluble, creates acid rain destroying woodlands and causing acidification of lakes with an impact on aquatic organisms. Nitrogen oxides $\left(\mathrm{NO}, \mathrm{NO}_{2}, \mathrm{NO}_{x}\right)$ are normally gaseous pollutants (40-50\%) of vehicles, but are also produced $(50 \%)$ by various combustion procedures at high temperatures. $\mathrm{NO}_{\mathrm{x}}$ worldwide emissions are estimated at 60 million tons (in the late 1980s), of which $54 \%$ come from OECD countries. $N O_{x}$ is another factor in the production of acid rain and contributes along with $\mathrm{CO}_{2}$ and methane $\left(\mathrm{CH}_{4}\right)$ to the rise of greenhouse effect[31-33]. Therefore, a special international treaty has been adopted to decrease atmospheric $\mathrm{NO}_{\mathrm{x}}$. Particulate matter (PM) is a variety of small particle diameters (from 50 to $0.1 \mu \mathrm{m}$ ) of various materials and combustions (soil dust, rubber powder, carbonaceous combustion particles, etc.) suspended in the atmosphere of urban and industrial areas. Total particulate emissions are estimated at 60 million tons in 1980 , of which $23 \%$ is due to OECD countries. The porous surface of the particles has the ability to absorb heavy metals, carcinogens and polycyclic aromatic hydrocarbons (PAHs), resulting in diseases and malignant neoplasms of the respiratory system. Epidemiological studies of recent decades show increased morbidity and mortality in urban areas due to high concentrations of suspended particulates (particularly small particles PM10, PM2.5, 10 and $2.5 \mu \mathrm{m}$ )[34]. Volatile Organic Compounds (VOCs) are primarily characterized by volatile aromatic compounds (such as benzene, toluene, xylenes, etc.) emitted into the atmosphere. The sources of VOCs are industries, vehicle exhausts, liquid fuel stations, paints and building materials. Although total emissions are difficult to calculate, the US was emitting approximately $17,580,000$ tons in 1990, Britain $2,600,000$ tons and Germany 2,545,000 tons[3537]. VOCs can remain in the atmosphere for 1-2 days, disintegrated into a wide variety of hydrocarbons. The polychlorinated organic compounds have an important role in photochemical reactions and contribute to environmental pollution because of their high toxic and carcinogenic effects. They are considered to be highly dangerous for human health. Polychlorinated organic compounds (dioxins, dibenzofurans, polychlorinated biphenyls; PCBs) are atmospheric air pollutants produced by various combustion emissions (car exhaust, forest fires, emissions from insulation materials), or pesticide use. PCBs were used as heat insulating and dielectric fluids in transformers, until banned in 1985. In recent decades, significant efforts have been made worldwide to reduce polychlorinated substances that are not biodegradable in the environment and bio accumulate through the food chain (pesticides, etc.). The Stockholm Convention on POPs (Persistent Organic Pollutants) aims at limiting the uses and emissions of polychlorinated substances with a priority to the restriction or prohibition of certain substances: aldrin, dieldrin, endrin, chlordane, heptachlor, hexachlorobenzene, mirex, toxaphene, polychlorinated biphenyls, dioxins, furans) [38]. Ozone $\left(\mathrm{O}_{3}\right)$ is a secondary atmospheric pollutant produced as a result of photochemical reactions between hydrocarbons and nitrogen oxides in the atmosphere. Owing to its oxidative capacity, ozone is considered a highly dangerous pollutant, both for human health and damaging to plants, trees and materials. Air pollution is not limited to the area where air pollutants are emitted, but it also affects neighboring countries through cross-border transfer. International conventions on the limitation and control of 
cross-border pollution have been signed ad hoc. In Europe, since 1979, the Convention on Long Range Transboundary Air Pollution (LRTAP) has been signed and controlled by the EMEP (Co-operative Program for the Monitoring and Evaluation of the Long-Range Transmission of Air Pollution in Europe). The original purpose was to control acid rain and eutrophication but expanded on ozone, polychlorinated compounds, heavy metals and suspended particles. The incineration of waste, toxic waste and biomass, is also another form of severe air pollution with gaseous pollutants, particles, dioxins and furans. Although technology has significantly improved with the incineration of municipal and industrial waste by using electrostatic filters at chimneys and high temperatures for toxic waste, the problem of air pollution still remains.

\subsection{Environmental Toxicology of Nitrogen Oxides}

The complex photochemical reactions occurring between organic and inorganic gaseous pollutants and volatile compounds have been studied and documented due to the production of secondary toxic pollutants posing a threat to human health and the environment. Photochemical reactions originate from the absorption of energy associated with solar radiation by certain substances, resulting in a change of their energy status. The electronic overstimulation caused, leads to the development of active substances, such as free radicals and ions, capable of chain reactions and the generation of secondary pollutants. The basic photochemical reactions carried out are results of solar ultraviolet (UV), reactive volatile hydrocarbons such as aldehydes, carbon monoxide $(\mathrm{CO})$ and oxides of nitrogen. The reactions triggered by this mixture lead to the production of the main active pollutants such as ozone $\left(\mathrm{O}_{3}\right)$, hydrogen peroxide $\left(\mathrm{H}_{2} \mathrm{O}_{2}\right)$, peroxyacetyl nitrate [(PAN: $\mathrm{CH}_{3} \mathrm{C}(\mathrm{O}) \mathrm{OONO}_{2}$ ] and its nitrogen peroxides through free radical mechanisms [39]. Ozone is photochemically produced by the oxidation of carbon dioxide $(C O)$ and VOCs by nitrogen oxides $\left(N O_{x}\right)$.

The carbonyl compounds produced by the process and the stages of the above mechanisms are photocatalyzed by the production of additional peroxyl-free radicals, eventually converted to ozone. The stage of reactions with a restrictive role in ozone production is the relative velocity the volatile organic compounds (VOCs) are disintegrated. The role of volatile organic compounds in the troposphere is an essential precondition for the various stages of photo-oxidative chain reactions.

Photochemical pollution causes significant health problems in the respiratory system of urban residents [40]. Exposure to high concentrations of nitrogen oxides, during photochemical cloud days in urban areas, increases morbidity and mortality (in association with suspended particles), inflammatory conditions of the respiratory system, asthma attacks, and other pneumococcal diseases [41]. Particular health problems of air pollution include children and elderly people with respiratory diseases [42-45]. A critical consequence of atmospheric pollutants is acid rain, caused by dry and wet precipitations or aerosol deposition. These precipitations are the result of sulphate $\left(\mathrm{SO}_{4}^{2-}\right)$ and nitrate $\left(\mathrm{NO}_{3}^{-}\right)$ions emitted into the atmosphere by anthropogenic activities, mainly combustion of high sulfur fossil fuels. Numerous studies have shown that acid precipitations or depositions have harmful effects on living organisms and ecosystems. The phenomenon of acid rain, a term proposed in 1872 by RA Smith, began to become more acute with the advent of the Industrial Revolution and the use of sulfur-rich fuels. Since the late 1970s, potential impacts on habitats, historical monuments, buildings and on human health have prompted many countries to study and legislate for limiting emissions, guilty of creating acidic depositions, e.g. the 10-year National Acid Precipitation Assessment Program of the US Congress in 1980. Acidic pollution is a cross-border issue of acidic aerosol transfer between countries and continents. Thence, both national and international researches and programs have been made so far to prevent and redress the impact, accompanied by published publications and reviews. To date, the attention of scientists has also focused on the effects of suspended particles and acidic depositions (sulphates and nitrates in particulates) on plant or animal species and ecosystems. Particulate matter is usually a mixture of sulphates $\left(\mathrm{SO}_{4}{ }^{2-}\right)$ and nitrates $\left(\mathrm{NO}_{3}{ }^{-}\right)$, organic or geological matter and carbonaceous microparticles. The percentages in urban areas are: $20 \%\left(\mathrm{SO}_{4}\right), 40 \%\left(\mathrm{NO}_{3}\right), 28 \%$ (organic substances), $10 \%$ (earthquake or geological composition) and 5\% (coal), but vary between $5-10 \%$ depending on region and the type of pollution [46]. The particles are deposited over a period of time on the surface of plants and trees, in water bodies and on the 
ground. Their impact on living beings and ecosystems is proportional to the size, composition and content of adsorbed toxic metals, organic substances, sulphates and nitrates. Effects on plants begin with inhibiting photosynthesis, reducing plant respiration and receiving nutrients from the soil, while other impacts concern the imbalance of nutrient emission from the leaves and the distribution of carbon in plant tissues. Regarding animals, particles can affect reproduction, genetic diversity, population density and distribution, as well as biodiversity. In terms of species community, they can affect the trophic levels, the distribution of root systems and trees, soil productivity and biomass. Effects of particles in ecosystems can occur in nutrient cycles, in the hydrological cycle and energy flow. Particulate matter has a wide variety of sizes and composition; toxic substances, heavy metals, acid and alkaline salts, rendering them critical for organisms, communities and ecosystems in areas where depositions are long- term and of high concentrations. Despite the significance of toxic effects referring to suspended particles on plants, animals and ecosystems, they have not been extensively studied to other gaseous and solid pollutants. The research on the effects of lime kiln dust, foundries and other particles on plants, forests and ecosystems is limited [47, 48]. However, the effects of particulates bearing significant amounts of sulphates and nitrates on plants and forests is a more systematic field and the implications have been recorded in several scientific studies and publications [49].

Heavy metals carried on particulate matter are main pollutants for plants, trees and soils. There are several studies on the effects of metals on forest health and ecosystems. Particular importance has been attributed by scientists to the toxicity of aluminum to plants and the mechanisms by which it acts on the roots of trees and plants.

Thus, exposure to nitrogen oxide pollutants concerns the professions most exposed to them than in everyday life, for instance those of drivers, industries producing combustion products or involving combustion processes. Studies have been made for such cases, for example the profession of commercial vehicle drivers [50-52]. In addition, conducted studies have shown that similar exposure to oxides occurs in casting, glass and metal construction industries [53-55]. Furthermore, exposure to pollutants in tunnels and road networks due to the traffic load are considered in the design and operation of pollution limitation in road and road tunnels by virtue of carbon monoxide $(\mathrm{CO})$, nitrogen oxides $\left(\mathrm{NO}_{2}, \mathrm{NO}_{x}\right)$ and soot load. Carbon monoxide $(\mathrm{CO})$ is emitted by all vehicles. The catalytic converters for automobiles and the new regulations for heavy vehicles have significantly reduced emissions which increase with speed, road inclination and altitude.

The generally accepted limit based on the PIARC guidelines is $100 \mathrm{ppm} / 15$ minutes. Health effects are not persistent; therefore, limits can reach $150 \mathrm{ppm}$ in extreme cases (congestion).

The regulations are based on WHO guidelines, which reduce the limit in the 2000 edition to 80ppm / 15 minutes. A corresponding reduction is expected in the regulations as well. Nitrogen dioxide $\left(\mathrm{NO}_{2}\right)$ is emitted from all vehicles along with nitric oxide $(N O)$, which is oxidized over a significant period of time in $\mathrm{NO}_{2}$. Overall, vehicle manufacturers and the PIARC guidelines give the total emission of both gases $\left(N O_{x}\right)$.

$\mathrm{NO}_{2}$ was not hitherto evaluated and monitoring $C O$ concentration concurrently covered $\mathrm{NO}_{2}$ concentration. However, by managing to reduce $\mathrm{CO}$ emissions the correspondence is no longer valid and $\mathrm{NO}_{2}$ should be taken into account in the dimensioning of ventilation.

On the whole, its exact effect on health and its acceptable limits remain uncertain. $\mathrm{NO}_{2}$ is harmful in very small concentrations to people with asthma and respiratory problems. The increased attention given to vulnerable population groups in recent years has led to a significant reduction of the permissible limits in the atmosphere.

The acceptable limits are in the range of $1 \mathrm{ppm}$, according to the PIARC guidelines. This concentration is clearly lower than the 8- hour exposure limits of Greek and British regulations in working environments. Guidelines of WHO give a $0.1 \mathrm{ppm} / 1$ hour limit in an urban environment, lower than the average annual value in most European cities.

The existing instruments in the market are inadequate for measuring such small concentrations suitable for each working environment, and measurements are basically made for both oxides $\left(\mathrm{NO}_{\mathrm{x}}\right)$. The percentage of $\mathrm{NO}_{2}$ is considered to be $8 \%-15 \%$, but there is also an uncertainty herein; for dimensioning of 
ventilation, PIARC suggests $\mathrm{NO}_{2} / \mathrm{NO}_{x}$ obtained at $10 \%$.

Therefore, as expected in the coming years, $\mathrm{NO}_{2}$ will be the pollutant determining the quantity and quality of the air chemistry. In order to confront the measurement difficulties, the $C O$ limits can be reduced to ensure that $\mathrm{NO}_{2}$ is also tested through technical inspection. Soot is emitted from diesel-powered passenger and heavy-duty vehicles. The transmission increases with the speed and inclination of the road network. The main effect of soot is the reduction of visibility and the generally accepted limit is $0.005 \mathrm{~m}-1$. Soot increases when velocity is small and in case of congestion and the value of 0.009 $\mathrm{m}^{-1}$ is acceptable; limits are therefore a function of velocity.

\subsection{Exposure to Oxides of Nitrogen and its Public Health Issues}

The issues raised are the mechanisms with which $N O_{x}$ affect human health and plants, and the symptoms and illnesses they induce when they exceed statutory limits. By the term nitrogen oxides is meant nitrogen monoxide $(\mathrm{NO})$ and nitrogen dioxide $\left(\mathrm{NO}_{2}\right)$ present in the air.

Nitrogen oxides (seven in number) are among the most serious pollutants with $\mathrm{NO}_{2}$ nitrogen dioxide predominant. A percentage of $50 \%$ of $N O_{x}$ emissions come from vehicles, it is produced as a by-product from the nitric and sulfuric acid through industrial processing, it is present in the nylon production, in the nitration of organic compounds and in the conversion of nitric oxide $(N O)$ to dioxide through photochemical conversions that occur in the atmosphere at high temperatures.

The damaging effect of nitrogen dioxide on plants begins at concentrations of $0.6 \mathrm{mg} / \mathrm{kg}$, causing inhibition of photosynthesis. At concentrations of $2 \mathrm{mg} / \mathrm{kg}$, the leaves are destroyed.

However, the most significant damaging effects are exerted on humans. Its limited solubility allows it to penetrate deep into the lower respiratory system. Irritations can begin at low concentrations of $15 \mathrm{ppm}$ (ppm: parts per million), by tingling in the eyes and nose. To 25 ppm, respiratory irritations begin with cough, shortness of breath or dyspnea, chest pain, a yellowish coating while coughing or blood cough, cyanosis, fever, asthma, increased respiratory rate, tracheobronchitis, bronchopneumonia and pulmonary edema.
Exposure to $150-200 \mathrm{ppm}$ may result in lethal pulmonary disease $[10,34]$.

Nitrogen dioxide also reacts with hemoglobin by generating inert compounds, mainly met hemoglobin, whose levels are also used as an indication of the amount of air pollution in monoxide and nitrogen dioxide. This prevents oxygenation of the tissues. The result is rapid hypertension and cardiac arrhythmia.

Nitrogen, which accounts for $78 \%$ of the volume of the atmosphere, forms various oxides of nitrogen during combustion in all internal combustion engines (e.g. cars) and all kiln and fossil fuels. The main nitrogen compound contained in car fuels is nitrogen monoxide.

The higher the combustion temperature, the greater the amount of nitrogen oxide formed. However, the process of combustion at high temperature means a good efficiency (energy) of the installation. Attempting to reduce combustion temperatures leads to lower $N O_{x}$ production, but deteriorates efficiency and increases energy consumption. Nitrogen monoxide is gasless and odorless. On the contrary, the dioxide has a strong odor and a red-yellow-brown color. Along with the suspended particles in the atmosphere, it reduces the brightness of the atmosphere and creates the photochemical smog[56].

Short-term exposure (e.g. for less than 3 hours) to current $\mathrm{NO}_{2}$ levels may result in respiratory irritations and increased respiratory illnesses such as childhood asthma (aged 5-12 years old). Prolonged exposure causes sensitivity of the respiratory system and may lead to severe, permanent lesions of the lung.

Nitrogen oxides contribute to the emergence of a variety of negative environmental impacts such as significant changes in the composition of certain species of wetland and terrestrial vegetation, the occurrence of acid rain, acidification and eutrophication of fresh water, reduced visibility, increased levels of toxins of various fish species and other aquatic animals, etc.

In the last two decades, particular importance has been given to the involvement of the endothelium in the function of the heart and vessels. The endothelium is the interior of the three layers (tunica externa, media and intima) of the vessel wall: it is like a "lining", a dividing surface between the vessel and the blood. Moreover, with the help of a large number of substances it produces, it has a central role both 
in the regulation of vascular mobility and in the way they interact with the blood components (red and white blood cells, platelets)[57-59].

Through production of substances such as nitrogen oxides ( $N O$ : substance produced by Larginine), prostacyclin and the EndotheliumDerived Hyperpolarizing Factor (EDHF), endothelium exerts a relaxing effect on smooth muscle cells of blood vessels, increases their diameters and hence the amount of blood they bring to the periphery. At the same time, it generates vasoconstrictor substances, such as endothelin, thromboxane and angiotensin, thereby adjusting the tone and diameter of vessels according to the needs of the tissues. The endothelium exhibits beneficial antithrombotic properties, since both nitric oxide and prostacyclin inhibit platelet aggregation by preventing the formation of blood clots that close the vessel and impede blood flow at the periphery. Finally, it prevents adhesion of leukocytes to the wall of the vessels and reduces vascular hyperplasia, thus participating in a substantial way in the inhibition of atherogenesis [57-59].

Given that normal endothelial function has a central role in cardiovascular homeostasis, it is perfectly reasonable to assume that endothelial dysfunction contributes to the pathogenesis of diseases characterized by vasoconstriction, extensive or abnormal vascular hyperplasia such as atherosclerosis, hypertension and cardiac inadequacy.

In recent years, through experimental studies in the brachial and coronary vessels, the endothelium dysfunction of both atherosclerosis and individuals with risk factors for coronary artery disease has been confirmed. People with hypertension, hypercholesterolemia, diabetes mellitus, smokers and the elderly were examined and found that their endothelium reacts by inducing vasoconstriction in conditions that should normally cause vasodilation. Moreover, it is assumed that endothelial dysfunction is proportional to the number of coexisting risk factors.

However, the involvement of endothelial dysfunction in the pathophysiology of coronary heart disease and other cardiovascular diseases is as evident as the need to discover ways to interfere and improve endothelial cell function. In this direction, experimental data and clinical studies are abundant and their results show that therapeutic interventions can be divided into those relating to hygiene-dietary measures and those relating to the administration of pharmaceuticals and other substances.

Public health issues have been well documented along with their deleterious effects concerning ambient air pollution. Many epidemiologic studies worldwide, have calculated that globally at least seven million deaths are annually attributable to the effects of air pollution [60]. Further on, several cohort studies have shown that both ambient air pollution as well as trafficderived pollution have devastating effects on human/public health [61, 62].

Furthermore, deleterious side-effects of pollutants concern children and prenatal status both of the fetuses as well as the mothers [6365].

\section{CONCLUSiOnS}

Nitrogen oxides are, undoubtedly, environmental pollutants of great importance. Their significant effects on the biology and ecobiology of living organisms are also a fact. The issue raised is the unwillingness to reduce these pollutants and the tendency of ignoring the repercussions. Modern way of life lead us to the formulation of safety rules and acceptable levels of pollutants. Yet, is this true? Are there really acceptable levels of pollution? In the light of recent discoveries concerning the role of endocrine disrupters it has been clear that even small concentrations of pollutants could have a devastating effect on cellular signaling and signal transduction with downstream implications for health. In that sense, drastic measures should be undertaken in order to reduce pollution levels as well as nitrogen oxides and further on, more research is required in order to understand the effects of nitrogen oxides on human health and physiology.

\section{REFERENCES}

[1] Bonberg, N., B. Pesch, N. Ulrich, S. Moebus, L. Eisele, A. Marr, M. Arendt, K.H. Jockel, T. Bruning, and $\mathrm{T}$. Weiss, The distribution of blood concentrations of lead $(\mathrm{Pb})$, cadmium $(\mathrm{Cd})$, chromium $(\mathrm{Cr})$ and manganese $(\mathrm{Mn})$ in residents of the German Ruhr area and its potential association with occupational exposure in metal industry and/or other risk factors, Int J Hyg Environ Health. 220, 9981005 (2017).

[2] Mbelambela, E.P., R. Hirota, M. Eitoku, S.M.J. Muchanga, H. Kiyosawa, K. Yasumitsu-Lovell, O.L. Lawanga, and N. Suganuma, Occupation exposed to road-traffic emissions and respiratory health among Congolese transit workers, particularly bus conductors, in 
Kinshasa: a cross-sectional study, Environ Health Prev Med. 22, 11 (2017).

[3] Xia, T., Y. Zhu, L. Mu, Z.F. Zhang, and S. Liu, Pulmonary diseases induced by ambient ultrafine and engineered nanoparticles in twenty-first century, Natl Sci Rev. 3, 416-429 (2016).

[4] Fernandez-Somoano, A., G. Hoek, and A. Tardon, Relationship between area-level socioeconomic characteristics and outdoor NO2 concentrations in rural and urban areas of northern Spain, BMC Public Health. 13, 71 (2013).

[5] Yanagisawa, Y., H. Nishimura, H. Matsuki, F. Osaka, and H. Kasuga, Personal exposure and health effect relationship for NO2 with urinary hydroxyproline to creatinine ratio as indicator, Arch Environ Health. 41, 41-8 (1986).

[6] Davis, D.L., M.L. Bell, and T. Fletcher, A look back at the London smog of 1952 and the half century since, Environ Health Perspect. 110, A734-5 (2002).

[7] Bell, M.L., D.L. Davis, and T. Fletcher, A retrospective assessment of mortality from the London smog episode of 1952: the role of influenza and pollution, Environ Health Perspect. 112, 6-8 (2004).

[8] Xing, Y.F., Y.H. Xu, M.H. Shi, and Y.X. Lian, The impact of PM2.5 on the human respiratory system, J Thorac Dis. 8, E69-74 (2016).

[9] Cai, H. and C. Wang, Surviving With Smog and Smoke: Precision Interventions?, Chest. 152, 925-929 (2017).

[10] Lum, S., V. Bountziouka, S. Sonnappa, A. Wade, T.J. Cole, S. Harding, J.C. Wells, C. Griffiths, P. Treleaven, R. Bonner, J. Kirkby, S. Lee, E. Raywood, S. Legg, D. Sears, P. Cottam, C. Feyeraband, and J. Stocks, Lung function in children in relation to ethnicity, physique and socioeconomic factors, Eur Respir J. 46, 166271 (2015).

[11] Gharibvand, L., W. Lawrence Beeson, D. Shavlik, R. Knutsen, M. Ghamsary, S. Soret, and S.F. Knutsen, The association between ambient fine particulate matter and incident adenocarcinoma subtype of lung cancer, Environ Health. 16, 71 (2017).

[12] Maher, A., M.F. Abdel Rahman, and M.Z. Gad, The Role of Nitric Oxide from Neurological Disease to Cancer, Adv Exp Med Biol. 1007, 71-88 (2017).

[13] Schultz, E., Fully Exploiting the Potential of the Periodic Table through Pattern Recognition, Journal of Chemical Education. 82, 1649 (2005).

[14] Cox, P.A., Transition metal oxides: an introduction to their electronic structure and properties. Vol. 27. 2010: Oxford university press.
[15] Greenwood, N. and A. Earnshaw, Chemistry of the elements, 2nd edn. Reed Educational and Professional. 1997, Oxford.

[16] Culotta, E. and D.E. Koshland Jr, NO news is good news, Science. 258, 1862-1866 (1992).

[17] DeRosa, F., L.K. Keefer, and J.A. Hrabie, Nitric oxide reacts with methoxide, The Journal of organic chemistry. 73, 1139-1142 (2008).

[18] 18. Osanai, T., N. Fujiwara, M. Saitoh, S. Sasaki, H. Tomita, M. Nakamura, H. Osawa, H. Yamabe, and K. Okumura, Relationship between salt intake, nitric oxide and asymmetric dimethylarginine and its relevance to patients with end-stage renal disease, Blood purification. 20, 466-468 (2002).

[19] Li, C.Q., B. Pang, T. Kiziltepe, L.J. Trudel, B.P. Engelward, P.C. Dedon, and G.N. Wogan, Threshold effects of nitric oxide-induced toxicity and cellular responses in wild-type and p53-null human lymphoblastoid cells, Chem Res Toxicol. 19, 399-406 (2006).

[20] Groves, J. and J.R. Cain, A survey of exposure to diesel engine exhaust emissions in the workplace, Ann Occup Hyg. 44, 435-47 (2000).

[21] Nunes, R.A.O., P. Branco, M.C.M. AlvimFerraz, F.G. Martins, and S.I.V. Sousa, Gaseous pollutants on rural and urban nursery schools in Northern Portugal, Environ Pollut. 208, 2-15 (2016).

[22] Taiwo, O.A., K.D. Sircar, M.D. Slade, L.F. Cantley, S.J. Vegso, P.M. Rabinowitz, M.G. Fiellin, and M.R. Cullen, Incidence of asthma among aluminum workers, J Occup Environ Med. 48, 275-82 (2006).

[23] Weisel, C.P., Assessing exposure to air toxics relative to asthma, Environ Health Perspect. 110 Suppl 4, 527-37 (2002).

[24] Chiri, E., P.A. Nauer, E.M. Rainer, J. Zeyer, and M.H. Schroth, High temporal and spatial variability of atmospheric-methane oxidation in Alpine glacier-forefield soils, Appl Environ Microbiol. (2017).

[25] D'Amato, G., C. Vitale, N. Rosario, H.J.C. Neto, D.C. Chong-Silva, F. Mendonca, J. Perini, L. Landgraf, D. Sole, M. SanchezBorges, I. Ansotegui, and M. D'Amato, Climate change, allergy and asthma, and the role of tropical forests, World Allergy Organ J. 10, 11 (2017).

[26] Friedrich, T., A. Timmermann, M. Tigchelaar, O. Elison Timm, and A. Ganopolski, Nonlinear climate sensitivity and its implications for future greenhouse warming, Sci Adv. 2, e1501923 (2016).

[27] Kump, L.R., Reducing uncertainty about carbon dioxide as a climate driver, Nature. 419, 188-190 (2002).

[28] Wang, S. and C. Li, The impact of urbanization on CO2 emissions in China: an empirical study 
using 1980-2014 provincial data, Environ Sci Pollut Res Int. (2017).

[29] Rowland, M., Climate change and human health: Possible communicable disease consequences in the United Kingdom, Medicine, Conflict and Survival. 11, 188-194 (1995).

[30] Root, T.L., J.T. Price, K.R. Hall, S.H. Schneider, C. Rosenzweig, and J.A. Pounds, Fingerprints of global warming on wild animals and plants, Nature. 421, 57-60 (2003).

[31] Hou, Y., G.L. Velthof, J.P. Lesschen, I.G. Staritsky, and O. Oenema, Nutrient Recovery and Emissions of Ammonia, Nitrous Oxide, and Methane from Animal Manure in Europe: Effects of Manure Treatment Technologies, Environ Sci Technol. 51, 375-383 (2017).

[32] Huyen, N.T., O. Desrues, S.J.J. Alferink, T. Zandstra, M.W.A. Verstegen, W.H. Hendriks, and W.F. Pellikaan, Inclusion of sainfoin (Onobrychis viciifolia) silage in dairy cow rations affects nutrient digestibility, nitrogen utilization, energy balance, and methane emissions, J Dairy Sci. 99, 3566-3577 (2016).

[33] Monster, J., J. Samuelsson, P. Kjeldsen, and C. Scheutz, Quantification of methane emissions from 15 Danish landfills using the mobile tracer dispersion method, Waste Manag. 35, 177-86 (2015).

[34] Pope, C.A., 3rd, R.T. Burnett, M.J. Thun, E.E. Calle, D. Krewski, K. Ito, and G.D. Thurston, Lung cancer, cardiopulmonary mortality, and long-term exposure to fine particulate air pollution, Jama. 287, 1132-41 (2002).

[35] Bolanca, T., T. Strahovnik, S. Ukic, M.N. Stankov, and M. Rogosic, Modeling of policies for reduction of GHG emissions in energy sector using ANN: case study-Croatia (EU), Environ Sci Pollut Res Int. 24, 16172-16185 (2017).

[36] Schwarzbock, T., H. Rechberger, O. Cencic, and J. Fellner, Determining national greenhouse gas emissions from waste-to-energy using the Balance Method, Waste Manag. 49, 263-271 (2016).

[37] Wilson, D., C.A. Farrell, D. Fallon, G. Moser, C. Muller, and F. Renou-Wilson, Multiyear greenhouse gas balances at a rewetted temperate peatland, Glob Chang Biol. 22, 40804095 (2016).

[38] Eduljee, G. and A. Gair, Validation of a methodology for modelling PCDD and PCDF intake via the foodchain, Science of the total environment. 187, 211-229 (1996).

[39] Kley, D., M. Kleinmann, H. Sanderman, and S. Krupa, Photochemical oxidants: state of the science, Environmental Pollution. 100, 19-42 (1999).
[40] Brunekreef, B. and S.T. Holgate, Air pollution and health, The lancet. 360, 1233-1242 (2002).

[41] Roemer, W., G. Hoek, and B. Brunekreef, Pollution effects on asthmatic children in Europe, the PEACE study, Clinical and experimental allergy. 30, 1067-1075 (2000).

[42] Sandstrom, T., R. Helleday, L. Bjermer, and N. Stjernberg, Effects of repeated exposure to 4 ppm nitrogen dioxide on bronchoalveolar lymphocyte subsets and macrophages in healthy men, European Respiratory Journal. 5, 1092-1096 (1992).

[43] Linaker, C.H., A.J. Chauhan, H. Inskip, A.J. Frew, A. Sillence, D. Coggon, and S.T. Holgate, Distribution and determinants of personal exposure to nitrogen dioxide in school children, Occupational and environmental medicine. 53, 200-203 (1996).

[44] Chauhan, A., M. Krishna, A. Frew, and S. Holgate, Exposure to nitrogen dioxide (NO2) and respiratory disease risk, Reviews on environmental health. 13, 73 (1998).

[45] Krishna, M., A. Chauhan, A. Frew, and S. Holgate, Toxicological mechanisms underlying oxidant pollutant-induced airway injury, Reviews on environmental health. 13, 59-71 (1998).

[46] Sisler, J.F. and W.C. Malm, Interpretation of Trends of PM25 and Reconstructed Visibility from the IMPROVE Network, Journal of the Air \& Waste Management Association. 50, 775-789 (2000).

[47] Zaharopoulou, A., T. Lanaras, and M. Arianoutsou, Influence of dust from a limestone quarry on chlorophyll degradation of the lichen Physcia adscendens (Fr.) Oliv, Bulletin of environmental contamination and toxicology. 50, 852-855 (1993).

[48] Geiser, L.H., A.R. Ingersoll, A. Bytnerowicz, and S.A. Copeland, Evidence of enhanced atmospheric ammoniacal nitrogen in Hells Canyon National Recreation Area: Implications for natural and cultural resources, Journal of the Air \& Waste Management Association. 58, 1223-1234 (2008).

[49] Wong, W., D.F. Fletcher, D. Traini, H.k. Chan, J. Crapper, and P.M. Young, Particle aerosolisation and break-up in dry powder inhalers: Evaluation and modelling of impaction effects for agglomerated systems, Journal of pharmaceutical sciences. 100, 27442754 (2011).

[50] Gertler, A., J. Gillies, W. Pierson, C. Rogers, J. Sagebiel, M. Abu-Allaban, W. Coulombe, L. Tarnay, and T. Cahill, Real-world particulate matter and gaseous emissions from motor vehicles in a highway tunnel, Research report (Health Effects Institute). 5-56; discussion 7992 (2002). 
[51] Son, B., W. Yang, P. Breysse, T. Chung, and Y. Lee, Estimation of occupational and nonoccupational nitrogen dioxide exposure for Korean taxi drivers using a microenvironmental model, Environmental research. 94, 291-296 (2004).

[52] Lewné, M., N. Plato, and P. Gustavsson, Exposure to particles, elemental carbon and nitrogen dioxide in workers exposed to motor exhaust, Annals of occupational hygiene. 51, 693-701 (2007).

[53] Schoonover, T., L. Conroy, S. Lacey, and J. Plavka, Personal exposure to metal fume, NO2, and $\mathrm{O} 3$ among production welders and nonwelders, Industrial health. 49, 63-72 (2011).

[54] Pronk, A., J. Coble, and P.A. Stewart, Occupational exposure to diesel engine exhaust: a literature review, Journal of exposure science and environmental epidemiology. 19, 443-457 (2009)

[55] Rafiei, M., A.S. Gadgil, V.S. Ghole, S.D. Gore, N. Jaafarzadeh, and R. Mirkazemi, Assessment of air pollution and its effects on the health status of the workers in beam rolling mills factory (Iran National Steel Industrial Group) from Ahvaz-Iran, Indian journal of occupational and environmental medicine. 13, 20 (2009).

[56] Kley, D., M. Kleinmann, H. Sanderman, and S. Krupa, Photochemical oxidants: state of the science, Environ Pollut. 100, 19-42 (1999).

[57] Fiorito, G., J. Vlaanderen, S. Polidoro, J. Gulliver, C. Galassi, A. Ranzi, V. Krogh, S. Grioni, C. Agnoli, C. Sacerdote, S. Panico, M.Y. Tsai, N. Probst-Hensch, G. Hoek, Z. Herceg, R. Vermeulen, A. Ghantous, P. Vineis, and A. Naccarati, Oxidative stress and inflammation mediate the effect of air pollution on cardio- and cerebrovascular disease: A prospective study in nonsmokers, Environ Mol Mutagen. (2017).

[58] Li, W., K.S. Dorans, E.H. Wilker, M.B. Rice, I. Kloog, J.D. Schwartz, P. Koutrakis, B.A. Coull, D.R. Gold, J.B. Meigs, C.S. Fox, and M.A.
Mittleman, Ambient air pollution, adipokines, and glucose homeostasis: The Framingham Heart Study, Environ Int. 111, 14-22 (2017).

[59] Patel, V., N. Kantipudi, G. Jones, A. Upton, and M.V. Kamath, Air Pollution and Cardiovascular Disease: A Review, Crit Rev Biomed Eng. 44, 327-346 (2016).

[60] Mannucci, P.M. and M. Franchini, Health Effects of Ambient Air Pollution in Developing Countries, Int J Environ Res Public Health. 14, (2017).

[61] Sorensen, M., O. Wendelboe Nielsen, A. Sajadieh, M. Ketzel, A. Tjonneland, K. Overvad, and O. Raaschou-Nielsen, Long-Term Exposure to Road Traffic Noise and Nitrogen Dioxide and Risk of Heart Failure: A Cohort Study, Environ Health Perspect. 125, 097021 (2017).

[62] Paulin, L.M., D.L. Williams, R. Peng, G.B. Diette, M.C. McCormack, P. Breysse, and N.N. Hansel, 24-h Nitrogen dioxide concentration is associated with cooking behaviors and an increase in rescue medication use in children with asthma, Environ Res. 159, 118-123 (2017).

[63] Alderete, T.L., A.Y. Song, T. Bastain, R. Habre, C.M. Toledo-Corral, M.T. Salam, F. Lurmann, F.D. Gilliland, and C.V. Breton, Prenatal traffic-related air pollution exposures, cord blood adipokines and infant weight, Pediatr Obes. (2017).

[64] Franklin, M. and S. Fruin, The role of traffic noise on the association between air pollution and children's lung function, Environ Res. 157, 153-159 (2017).

[65] Stingone, J.A., T.J. Luben, S.L. Carmichael, A.S. Aylsworth, L.D. Botto, A. Correa, S.M. Gilboa, P.H. Langlois, W.N. Nembhard, J. Richmond-Bryant, G.M. Shaw, and A.F. Olshan, Maternal Exposure to Nitrogen Dioxide, Intake of Methyl Nutrients, and Congenital Heart Defects in Offspring, Am J Epidemiol. 186, 719-729 (2017).

Citation: Margarita Theodorakidou \& George I. Lambrou. Public Health Issues from the Exposure to Nitrogen Oxides: A Brief Review. ARC Journal of Public Health and Community Medicine.2017; 2(4):44-56. DOI: dx.doi.org/ 10.20431/2456-0596.0204008.

Copyright: (C) 2017 Authors. This is an open-access article distributed under the terms of the Creative Commons Attribution License, which permits unrestricted use, distribution, and reproduction in any medium, provided the original author and source are credited. 